\title{
Inhibiting the NF-кB pathway enhances the antitumor effect of cabazitaxel by downregulating Bcl-2 in pancreatic cancer
}

\author{
ZEQUN LI ${ }^{1-4}$, ZEFENG XUAN ${ }^{1-4}$, JIAN CHEN $^{1-4}$, WENFENG SONG ${ }^{1-4}$, SHIYU ZHANG $^{1-4}$, CHENG JIN $^{1-4}$, \\ MENGQIAO ZHOU ${ }^{1-4}$, SHUSEN ZHENG ${ }^{1-4}$ and PENGHONG SONG ${ }^{1-4}$ \\ ${ }^{1}$ Division of Hepatobiliary and Pancreatic Surgery, Department of Surgery, First Affiliated Hospital, School of Medicine, \\ Zhejiang University; ${ }^{2}$ NHC Key Laboratory of Combined Multi-organ Transplantation, First Affiliated Hospital, \\ School of Medicine, Zhejiang University; ${ }^{3}$ Key Laboratory of the Diagnosis and Treatment of Organ Transplantation, \\ Research Unit of Collaborative Diagnosis and Treatment For Hepatobiliary and Pancreatic Cancer, \\ Chinese Academy of Medical Sciences; ${ }^{4}$ Key Laboratory of Organ Transplantation, First Affiliated Hospital, \\ School of Medicine, Zhejiang University, Zhejiang, Hangzhou 310003, P.R. China
}

Received August 28, 2019; Accepted February 28, 2020

DOI: $10.3892 /$ ijo.2020.5053

\begin{abstract}
Optimizing the currently available treatment options for pancreatic cancer (PC) is a priority. Cabazitaxel (CTX), a semisynthetic taxane, is mainly used for treating patients with PC who are resistant to paclitaxel (PTX) or docetaxel, due its poor affinity for P-glycoprotein. However, there are only a few studies demonstrating the effect of CTX on PC. The present study aimed to investigate the efficiency and underlying mechanism of CTX in PC treatment. Cell proliferation, colony formation assay and apoptosis analysis were achieved in the two human PC cell lines AsPC-1 and BxPC-3. Drug sensitivity test was performed in $\mathrm{BxPC}-3$ tumor-bearing mice. The results demonstrated that CTX had a lower half maximal inhibitory concentration compared with PTX for the inhibition of cell proliferation, both in vivo and in vitro. Furthermore, the nuclear factor $-\kappa \mathrm{B}(\mathrm{NF}-\kappa \mathrm{B})$ pathway was activated following cell treatment with CTX, and NF- $\kappa$ B p65 overexpression attenuated CTX cytotoxicity. In addition, the combined use of the specific $\mathrm{NF}-\kappa \mathrm{B}$ inhibitor caffeic acid phenethyl ester (CAPE) with CTX significantly enhanced CTX effect, both in vivo and in vitro. Similarly, the mRNA and protein expression of B-cell lymphoma-2 was decreased in AsPC-1 and BxPC-3 cells following treatment with CTX
\end{abstract}

Correspondence to: Professor Shusen Zheng or Dr Penghong Song, Division of Hepatobiliary and Pancreatic Surgery, Department of Surgery, First Affiliated Hospital, School of Medicine, Zhejiang University, 79 Qinchun Road, Hangzhou, Zhejiang 310003, P.R. China E-mail: shusenzheng@zju.edu.cn

E-mail: songpenghong@zju.edu.cn

Abbreviations: CTX, cabazitaxel; CAPE, caffeic acid phenethyl ester; DTX, docetaxel; PC, pancreatic cancer; PCNA, proliferating cell nuclear antigen; PTX, paclitaxel

Key words: pancreatic cancer, cabazitaxel, nuclear factor- $\kappa \mathrm{B}$, caffeic acid phenethyl ester, apoptosis, B-cell lymphoma-2 and CAPE, suggesting that $\mathrm{NF}-\kappa \mathrm{B}$ may serve a crucial role in CTX efficiency. In conclusion, results from our previous study indicated that CTX could potentially replace PTX in the treatment of PC, and the present study demonstrated that CTX combination with an NF- $\kappa \mathrm{B}$ inhibitor may be considered as a potential therapeutic option for $\mathrm{PC}$, which may improve the prognosis of patients with PC.

\section{Introduction}

Pancreatic cancer (PC) is one of the leading causes of cancer-associated mortality and one of the most lethal malignancies worldwide with a 5-year survival rate $<10 \%$ (1). Surgical resection is the only available treatment for PC, followed by adjuvant chemotherapy with gemcitabine plus albumin-bound paclitaxel (PTX) administration following surgery (2). Because of PC tumor biology, early metastasis, recurrence and resistance to chemotherapy are common in patients with $\mathrm{PC}(2,3)$. It is therefore crucial to develop effective therapies for patients with $\mathrm{PC}$ following resection.

Cabazitaxel (CTX), PTX and docetaxel (DTX) are taxane anticancer drugs that bind to tubulin and subsequently suppress microtubule dynamics in cell division, leading therefore to cancer cell death $(4,5)$. CTX is mainly used to treat PC in patients with resistance to PTX or DTX, due to its poor affinity for P-glycoprotein (P-gp) compared with PTX and DTX (6). Previous studies demonstrated that CTX is also suitable for the treatment of lung and breast cancers, hepatocellular carcinoma and other types of cancer (7-10). Two previous studies reported that CTX or modified CTX might be effective in PC $(11,12)$; however, whether CTX may be suitable for the treatment of PC requires further investigation.

Nuclear factor- $\kappa \mathrm{B}(\mathrm{NF}-\kappa \mathrm{B})$ is a transcription factor involved in inflammation and immunity (13). However, numerous studies reported that it could also regulates cell proliferation, apoptosis and cell migration in various types of cancer cells. For example, activation of the NF- $\mathrm{BB}$ pathway often acts as a cancer promoter by regulating the anti-apoptotic B-cell lymphoma-2 (Bcl-2) 
gene $(14,15)$. Furthermore, the downregulation or inhibition of $\mathrm{NF}-\kappa \mathrm{B}$ activation is an effective treatment option for certain types of cancer, including colorectal cancer, glioblastoma, breast cancer and lung cancer $(16,17)$. It has been reported that NF- $\mathrm{NB}$ p65 directly bound to NME5 serves a central role in $\mathrm{PC}$ chemoresistance by inhibiting gemcitabine-induced apoptosis and G1 phase arrest (18). In particular, previous studies reported that PTX and DTX can induce NF- $\kappa$ B activation $(19,20)$, suggesting that $N F-\kappa B$ might be a crucial factor involved in PC chemoresistance. Combination of a taxane anticancer drug with an $\mathrm{NF}-\kappa \mathrm{B}$ inhibitor may therefore be considered as a more effective cancer treatment option. Caffeic acid phenethyl ester (CAPE), which is a NF- $\kappa B$ inhibitor capable of inhibiting the translocation of NF- $\mathrm{B}$ p 65 subunit to the nucleus, was used in a previous study (21). The results from this study demonstrated that the effect of CAPE on the inhibition of NF- $\kappa \mathrm{B}$ binding to DNA sequences is specific (21).

The present study aimed to investigate the efficiency and potential mechanism of CTX in the treatment of patients with PC. The results from this study may serve the development of novel treatment plan for PC.

\section{Materials and methods}

Chemicals and antibodies. CTX and PTX were purchased from Dalian Meilun Biology Technology Co.,Ltd.CAPE was purchased from Selleck Chemicals. Primary antibodies against GAPDH (1:2,000; cat. no. ab181602), $\beta$-actin (1:2,000; cat. no. ab8227), Bcl-2 (1:2,000; cat. no. ab196495), Histone H3 (1:2,000; cat. no. ab1791) and proliferating cell nuclear antigen (PCNA) (1:5,000; cat. no. ab18197) were obtained from Abcam. The NF-кB Pathway Sampler Kit (cat. no. 9936) and Apoptosis Antibody Sampler Kit (containing caspase-3, cleaved-caspase-3, poly(ADP-ribose) polymerase (PARP), cleaved-PARP, caspase-9, cleaved-caspase-9, caspase-7, cleaved-caspase-7, anti-rabbit IgG and anti-mouse IgG antibodies; cat. no. 9915) were purchased from Cell Signaling Technology, Inc.

Cell lines and cell culture. Two human PC cell lines, AsPC-1 and BxPC-3, were used in the present study (China Center for Type Culture Collection). Both cell lines were cultured in RPMI-1640 (Biological Industries) supplemented with $10 \%$ fetal bovine serum (Biological Industries) and placed at $37^{\circ} \mathrm{C}$ in a humidified incubator containing $5 \% \mathrm{CO}_{2}$.

Cell proliferation assay. AsPC-1 and BxPC-3 cell proliferation was detected using Cell Counting Kit-8 (MedChemExpress). A total of 5,000 cells per well were seeded in 96-well plates and cultured at $37^{\circ} \mathrm{C}$ in an incubator for $24 \mathrm{~h}$. Cells were then treated with PTX $(0,1,5,10,20,40,80,100$ or $120 \mathrm{nM})$ or CTX $(0$, $0.5,1,2,4,5,7.5,10,20$ or $40 \mathrm{nM})$ or CAPE $(0,1,5,10,15$, $20,25,30,40$ or $50 \mu \mathrm{M})$ or CTX $(0,0.5,1,2,4,5,7.5,10,20$ or $40 \mathrm{nM})$ and $5 \mu \mathrm{M}$ CAPE or CTX $(0,0.8,2,4$ or $8 \mathrm{nM})$ and CAPE $(0,1,5,10$ or $15 \mu \mathrm{M})$ for $48 \mathrm{~h}(8,21)$. Cells were then incubated in $100 \mu \mathrm{l}$ medium containing $10 \%$ of Cell Counting Kit-8 (CCK-8) reagent for $1 \mathrm{~h}$. Absorbance was read at $450 \mathrm{nM}$ using a microplate reader (Bio-Rad Laboratories, Inc.).

Colony formation assay. PC cells were seeded in 6-well plates at the density of 2,000 cells per well and cultured for
$24 \mathrm{~h}$, followed by treatment with or without drug for $48 \mathrm{~h}$. Cells were maintained in an incubator with $5 \% \mathrm{CO}_{2}$ at $37^{\circ} \mathrm{C}$ for 7 days. Subsequently, the medium was removed, and cells were washed twice by PBS and fixed with methanol at room temperature for $10 \mathrm{~min}$. Cell clones were stained with Giemsa for $2 \mathrm{~min}$, washed with deionized water and photographed with a camera (Nikon D3500; Nikon Corporation).

Cell transfection. The lentiviral vectors (CMV-MCS-EF1 $\alpha-$ GFP-Puro) containing human NF- $\mathrm{B}$ p65 or a non-target control (Zorin) were used to establish stable cell transfectants. PC cells were seeded in 6-well plates at the density of 200,000 cells per well and were infected by $2,000,000 \mathrm{UT}$ lentivirus (MOI value of AsPC-1 and BxPC-3=10) by using polybrene (Sigma-Aldrich; Merck KGaA; $5 \mu \mathrm{l} / \mathrm{ml}$ ). Medium was changed after $8 \mathrm{~h}$. Successfully transfected PC cells were selected by using $5 \mu \mathrm{g} / \mathrm{ml}$ puromycin (MedChemExpress) following $48 \mathrm{~h}$ transfection. The lentivirus transfection efficiency was validated by western blotting and with the expression of green fluorescent protein $(488 \mathrm{~nm})$.

Apoptosis analysis. AsPC-1 and BxPC-3 cells were harvested following treatment with 5 and $10 \mathrm{nM} \mathrm{CTX}$, or $5 \mu \mathrm{M}$ CAPE, or $5 \mu \mathrm{M}$ CAPE and $5 \mathrm{nM}$ CTX, or DMSO for $48 \mathrm{~h}$. Cells were washed twice with PBS and subsequently stained with $5 \mu \mathrm{l}$ Annexin V-FITC and $5 \mu \mathrm{l}$ propidium iodide (PI; cat. no. AD10; Dojindo Molecular Technologies, Inc.) in the dark at room temperature for $15 \mathrm{~min}$. PC cell apoptosis was detected by using a FACSCalibur flow cytometer and analyzed using FlowJo V10 software (BD Biosciences).

Cell cycle analysis. For cell cycle analysis, AsPC-1 and BxPC-3 cells were harvested following treatment with 5 and $10 \mathrm{nM}$ CTX, or $5 \mu \mathrm{M}$ CAPE, or $5 \mu \mathrm{M}$ CAPE and $5 \mathrm{nM}$ CTX, or DMSO for $48 \mathrm{~h}$. Cells were washed twice with PBS and fixed with $75 \%$ ethanol at $-20^{\circ} \mathrm{C}$ overnight. Subsequently, cells were washed with PBS and were stained with DNA Prep (Beckman Coulter, Inc.) for $30 \mathrm{~min}$ in the dark. The percentage of cells in the G1, S and G2/M phases was detected by FACSCalibur flow cytometry (BD Biosciences) and analyzed using Modifit LT 5.0 software.

Western blotting. AsPC-1 and BxPC-3 cells were treated with 5 and $10 \mathrm{nM} \mathrm{CTX,} \mathrm{or} 5 \mu \mathrm{M}$ CAPE, or $5 \mu \mathrm{M}$ CAPE and $5 \mathrm{nM}$ CTX, or DMSO for $48 \mathrm{~h}$, or stably transfected for $\mathrm{NF}-\kappa \mathrm{B}$ p65 overexpression or infected by non-target control lentivirus. Cells were then lysed using RIPA buffer (Thermo Fisher Scientific, Inc.) supplemented with phosphatase inhibitors (1:100; Thermo Fisher Scientific, Inc.) for $30 \mathrm{~min}$ on ice. Cell lysate was centrifuged at $14,000 \mathrm{x}$ g for $15 \mathrm{~min}$ at $4^{\circ} \mathrm{C}$ to extract the proteins. The NE-PER Nuclear and Cytoplasmic Extraction Reagent Kit (cat. no. 78835; Thermo Fisher Scientific, Inc.) was used to separate the nuclear and cytoplasmic proteins. The BCA Protein Assay Kit (Thermo Fisher Scientific, Inc.) was used to quantify proteins in each fraction. Proteins $(30 \mu \mathrm{g})$ were separated using SurePAGE ${ }^{\mathrm{TM}}$ gels $4-20 \%$ (GenScript) and transferred onto polyvinylidene fluoride membranes (EMD Millipore). Membranes were incubated with the blocking buffer (TBS with Tween-20 containing $5 \%$ skim milk) at room temperature for $1 \mathrm{~h}$. Membranes were 
incubated with primary antibodies at $4^{\circ} \mathrm{C}$ overnight and with horseradish peroxidase-linked secondary antibody at room temperature for $1 \mathrm{~h}$. Enhanced chemiluminescence reagent (Fdbio Science) was used to detect the signal on the membrane.

Immunofluorescence. AsPC-1 and BxPC-3 cells were seeded in 24-well plates at the density of $1.5 \times 10^{4}$ cells per well and treated with $10 \mathrm{nM}$ CTX for $0,1,3$ and $6 \mathrm{~h}$ and washed with PBS. Cells were subsequently fixed with $4 \%$ paraformaldehyde at room temperature for $15 \mathrm{~min}$ and washed three times with PBS. Cells were blocked with PBS containing 4\% BSA (cat. no. abs9157; Absin) and $0.5 \%$ Triton at room temperature for $1 \mathrm{~h}$. Cells were then incubated with antibody against NF- $\mathrm{B}$ p 65 at $4{ }^{\circ} \mathrm{C}$ overnight. Following incubation with fluorescence-tagged secondary antibody $(5 \mu \mathrm{g} / \mathrm{ml}$; cat. no. A27034; Thermo Fisher Scientific, Inc.) for $1 \mathrm{~h}$ and staining with DAPI, cells were imaged using a fluorescent microscope (magnification, x200; Olympus Corporation).

Reverse transcription quantitative $(R T-q) P C R$. Total RNA was extracted from AsPC-1 and BxPC-3 cells using NucleoZOL (Macherey-Nagel $\mathrm{GmbH}$ ) and reverse transcribed into cDNA using Takara PrimeScript ${ }^{\mathrm{TM}}$ RT reagent Kit with gDNA Eraser (Takara Bio Inc.) according to the manufacturer's instructions. ChamQTM Universal SYBR qPCR Master Mix (Vazyme Biotech Co., Ltd.) was used and RT-qPCR was performed on an Applied Biosystems ${ }^{\mathrm{TM}} 7500$ Fast Dx Real-Time PCR Instrument (Thermo Fisher Scientific, Inc.) according to the following reactions: Step $1,95^{\circ} \mathrm{C}$ for $30 \mathrm{sec}$; and step 2, 40 cycles of $95^{\circ} \mathrm{C}$ for $10 \mathrm{sec}$ and $60^{\circ} \mathrm{C}$ for $30 \mathrm{sec}$. The sequences of the primers (Tsingke Biological Technology, Co., Ltd.) were as follows: Bcl-2, forward, 5'-GCCCTGTGGATGACTGAGTA-3', reverse, 5'-AGCCAGGAGAAATCAAACAGAG-3'; and GAPDH, forward, 5'-GAGCCAAAAGGGTCATCATCT-3', and reverse, 5'-TTCCACGATACCAAAGTTGTCA-3'. GAPDH was used as an internal control for normalization. Each sample was analyzed in triplicate. The relative expression levels were normalized to GAPDH and were expressed as $2^{-\Delta \Delta C q}(22)$.

Antitumor activity in tumor-bearing mice. A total of 25 male athymic nude (nu/nu) mice aged 4-5 weeks were provided by Shanghai SLAC Laboratory Animal Co., Ltd. Animal care and experiments were conducted according to the Guidelines of the Zhejiang University Animal Care Committee (China) and were approved by the Tab of Animal Experimental Ethical Inspection of the First Affiliated Hospital, College of Medicine, Zhejiang University. Briefly, BxPC-3 cells $\left(4 \times 10^{6}\right)$ in $100 \mu 1$ PBS were injected into the right flank of the mice. Two weeks after inoculation, mice were divided into five groups ( $n=5$ per group) according to the treatment they received as follows: Control, no drug treatment; CAPE (10 mg/kg); PTX (10 mg/kg); CTX (10 mg/kg); and CTX (8 mg/kg) with CAPE $(10 \mathrm{mg} / \mathrm{kg})$. Drugs were dissolved in a mixture of DMSO, Tween-80 and saline (1:1:38 ratio), and the control group received only DMSO, Tween-80 and saline (1:1:38 ratio). The treatment was injected around the tumors every three days and for three cycles. The width and length of the tumors were measured every time before treatment. At the end of the experiment, mice were sacrificed by cervical dislocation following anesthesia by intraperitoneal injection of chloral hydrate $(400 \mathrm{mg} / \mathrm{kg})$. Tumors were subsequently removed and preserved in formalin. Tumor volume was calculated according to the following formula: length $\mathrm{x}$ width ${ }^{2} \mathrm{x} 0.5\left(\mathrm{~cm}^{3}\right)$.

Immunohistochemistry (IHC) and TUNEL staining assay. To detect PC cell proliferation and apoptosis in mice tumor, paraffin-embedded tissues were cut into 4- $\mu \mathrm{m}$ slices, deparaffinized and rehydrated by dimethylbenzene and ethanol. Antigen was retrieved by using citrate buffer $(\mathrm{pH}$ 6.0) for 15 min and slices were washed three times with PBS. Sections were incubated with $3 \% \mathrm{H}_{2} \mathrm{O}_{2}$ for $10 \mathrm{~min}$ at room temperature and washed three times with PBS. One part of the slices was used for IHC and the other parts were used for the TUNEL assay. For IHC, slices were incubated with PCNA antibody $(1: 5,000)$ overnight at $4^{\circ} \mathrm{C}$, washed with PBS, and incubated with the secondary antibody (cat. no. SAP9100; OriGene Technologies, Inc.) for $30 \mathrm{~min}$ at $37^{\circ} \mathrm{C}$. Sections were washed three times with PBS and stained with the 3'-diaminobenzidine (DAB) for $1 \mathrm{~min}$. Subsequently, DAB staining was stopped by washing in running water and sections were counterstained using hematoxylin. Sections were imaged using a microscope (Olympus Corporation; magnification, x200). For the TUNEL assay, sections were stained according to the manufacturer's instructions by using the One Step TUNEL Apoptosis Assay Kit (Beyotime Institute of Biotechnology). Sections were imaged using a fluorescent microscope (Olympus Corporation; magnification, $\mathrm{x} 200)$.

Statistical analysis. Data were presented as the means \pm standard error of the mean and were calculated using SPSS version 22.0 (IBM Corp.) and Prism GraphPad 6.02 (GraphPad Software, Inc.). Differences between two groups were calculated using Student's t-test. ANOVA followed by Tukey's test were used to calculate the differences among multiple groups. $\mathrm{P}<0.05$ was considered to indicate a statistically significant difference.

\section{Results}

CTX is more effective than PTX in PC cells. The effect of CTX and PTX on the proliferation of the PC cell lines AsPC-1 and BxPC-3 was evaluated by using the CCK- 8 assay. As presented in Fig. 1A and Table I, after assessing the inhibition curve of cell proliferation in a drug concentration gradient after $48 \mathrm{~h}$ of drug treatment, the results demonstrated that CTX had a lower $\mathrm{IC}_{50}$ value compared with PTX in the two PC cell lines. Furthermore, the results from the colony formation assay demonstrated that the colony number and size in the CTX group was lower and smaller, respectively, compared with the PTX group (10 nM; Fig. 1B). Following PC cell treatment with $10 \mathrm{~nm}$ PTX or CTX for $48 \mathrm{~h}$, Annexin V-FITC and PI staining was used to assess apoptosis. The results demonstrated that apoptosis was significantly higher in the CTX group compared with the PTX group in the two PC cell lines (Fig. 1C-E). Expression of apoptosis-related proteins was also evaluated. The results from western blotting demonstrated that CTX led to a decline expression of the anti-apoptotic protein Bcl-2 and an increased cleavage of caspase-3, caspase-7, caspase- 9 and PARP (Fig. 1F). Furthermore, the effect of treatment with $10 \mathrm{nM}$ CTX on cell cycle arrest was examined in the AsPC-1 
A

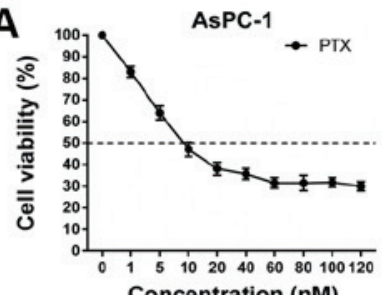
Concentration (nM)

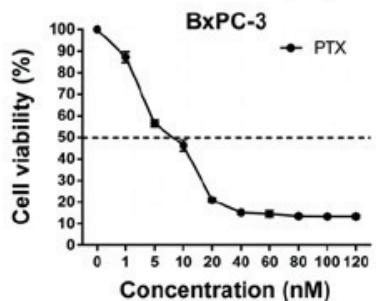
Concentration (nM)

C

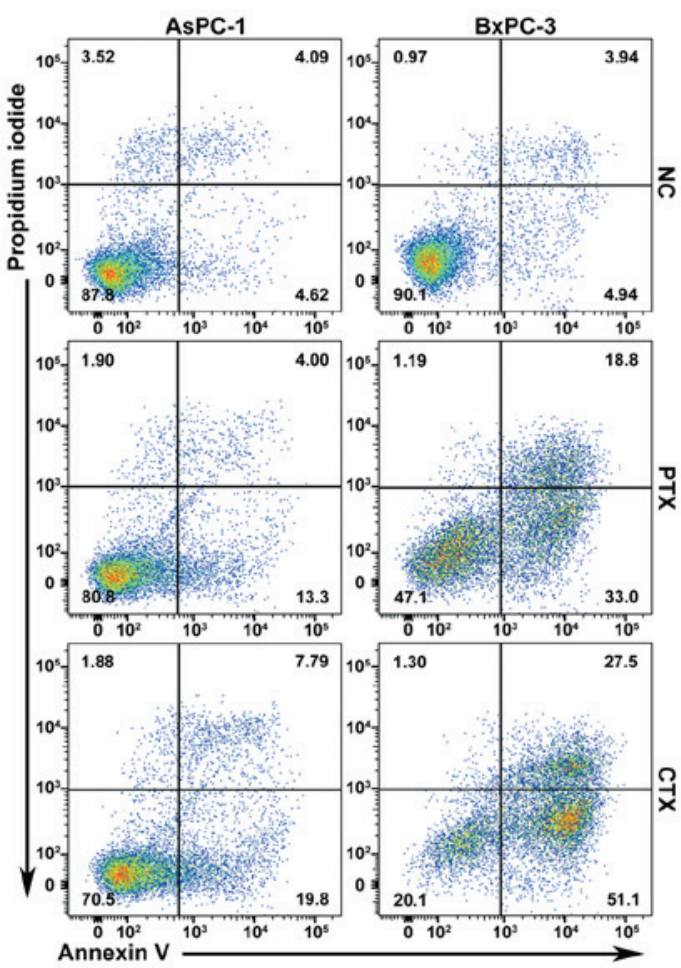

AsPC-1

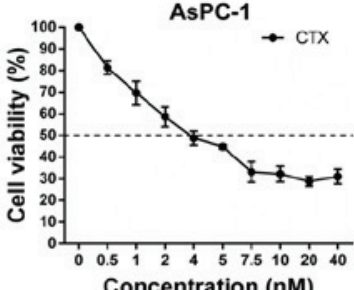

BxPC-3

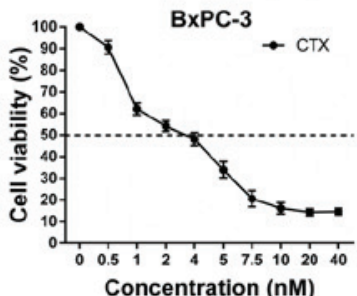

B

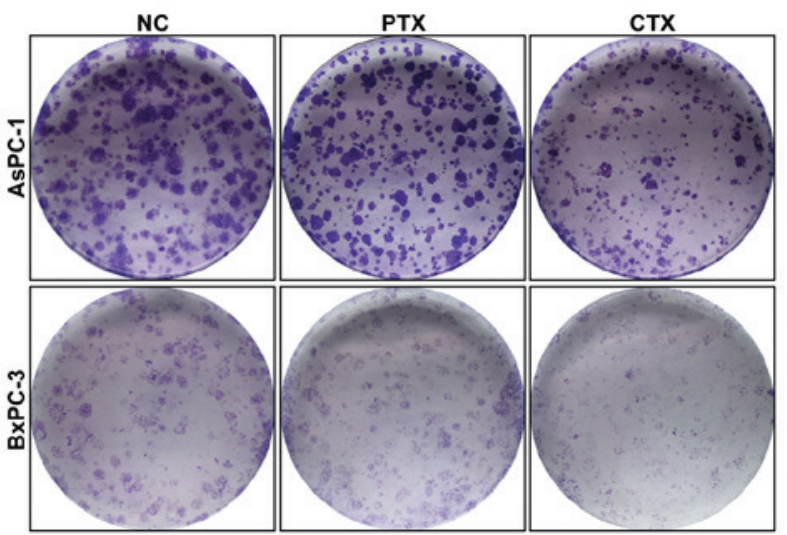

D

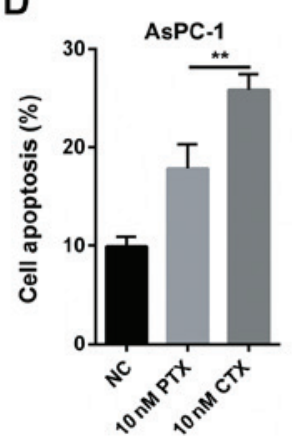

$\mathbf{F}$
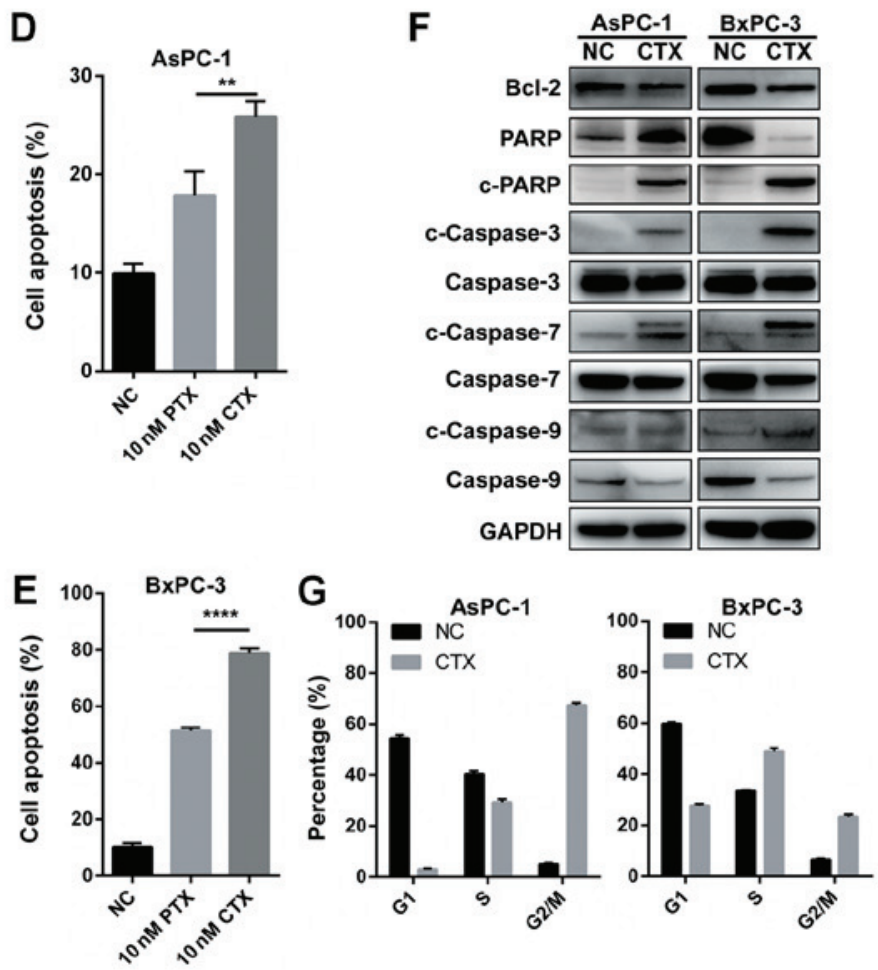

Figure 1. CTX was more effective than PTX in promoting apoptosis and cell cycle arrest. (A) AsPC-1 and BxPC-3 cell proliferation was detected using Cell Counting Kit-8 assay following treatment with different concentrations of PTX and CTX (0-120 nM and 0-40 nM, respectively) for $48 \mathrm{~h}$. (B) Colony formation of AsPC-1 and BxPC-3 cells following treatment with $10 \mathrm{nM}$ PTX or $10 \mathrm{nM} \mathrm{CTX}$ for $48 \mathrm{~h}$ and maintained in an incubator with $5 \%$ CO ${ }_{2}$ at $37^{\circ} \mathrm{C}$ for 7 days. (C) Apoptosis analysis following cell treatment with $10 \mathrm{nM}$ PTX or $10 \mathrm{nM} \mathrm{CTX.} \mathrm{Quantification} \mathrm{of} \mathrm{cell} \mathrm{apoptosis} \mathrm{in} \mathrm{(D)} \mathrm{AsPC-1} \mathrm{and} \mathrm{(E)} \mathrm{BxPC-3} \mathrm{cell} \mathrm{lines.} \mathrm{Data}$ were presented as the means \pm standard error of the mean of three independent experiments. In AsPC-1 cell line, the $10 \mathrm{nM}$ PTX group apoptosis rate compared with the $10 \mathrm{nM}$ CTX group ${ }^{* *} \mathrm{P}<0.01$. In BxPC-3 cell line, the $10 \mathrm{nM}$ PTX group apoptosis rate compared with the $10 \mathrm{nM}$ CTX group ${ }^{* * * * *} \mathrm{P}<0.0001$. (F) Western blotting of apoptosis-related proteins in PC cells following treatment with $10 \mathrm{nM}$ CTX for 48 h. (G) Quantification of cell cycle analysis from Fig. S1. c, cleaved; CTX, cabazitaxel; NC, negative control; PARP, poly (ADP-ribose) polymerase; PC, prostate cancer; PTX, paclitaxel.

Table I. Drug sensitivity of AsPC-1 and BxPC-3 cell lines to cabazitaxel.

\begin{tabular}{lcc}
\hline $\begin{array}{l}\text { Drug } \\
(48 \text { h treatment })\end{array}$ & $\begin{array}{c}\text { AsPC-1 } \mathrm{IC}_{50} \\
\mathrm{nM}\end{array}$ & $\begin{array}{c}\mathrm{BxPC}-3 \mathrm{IC}_{50} \\
\mathrm{nM}\end{array}$ \\
\hline Paclitaxel & $13.010 \pm 1.780$ & $7.056 \pm 0.636$ \\
Cabazitaxel & $3.772 \pm 0.465$ & $2.507 \pm 0.262$ \\
Cabazitaxel $+5 \mu \mathrm{M}$ & $1.440 \pm 0.273$ & $0.917 \pm 0.187$ \\
caffeic acid & & \\
phenethyl ester & & \\
\hline
\end{tabular}

and BxPC-3 cell lines. The results demonstrated that cell cycle arrest in the AsPC-1 and BxPC-3 cell lines, and the proportion of cells in the G2/M phase was increased (Fig. 1G and S1). Taken together, these findings suggested that CTX may inhibit PC cell proliferation mostly by promoting cell apoptosis and cell cycle arrest; however, no association between cell apoptosis and cell cycle arrest was determined.

$C T X$ promotes the translocation of $N F-\kappa B$ p65 to the nucleus and activates the $N F-\kappa B$ pathway. Previous studies reported that taxanes can induce the translocation of $N F-\kappa B$ to the nucleus, which is crucial to the activation of the $N F-\kappa B$ 

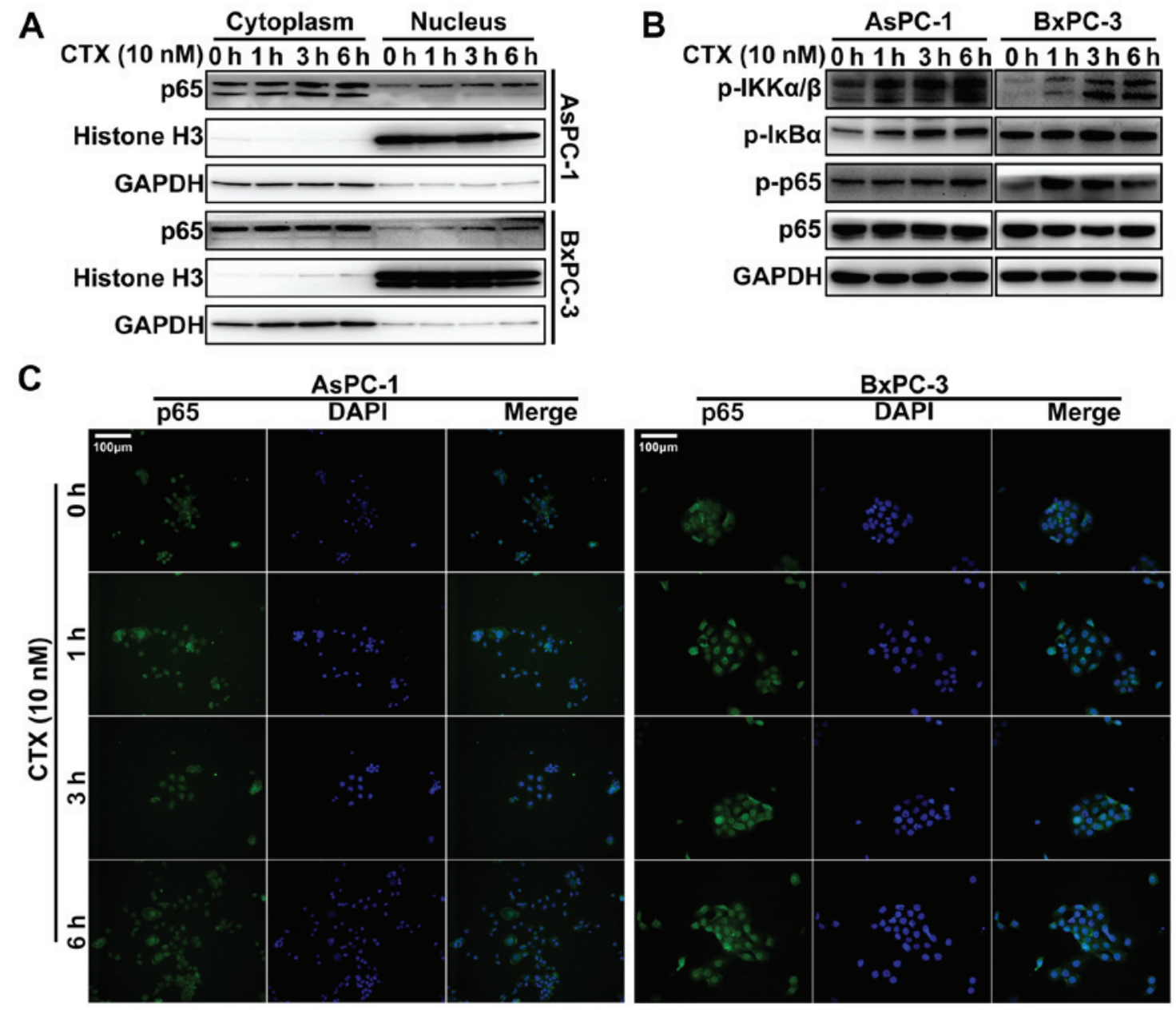

Figure 2. NF- $\mathrm{kB}$ was activated in PC cells following treatment with CTX. (A) NF- $\mathrm{kB}$ p65 protein expression in the nucleus was detected by western blotting

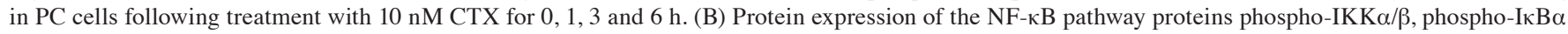

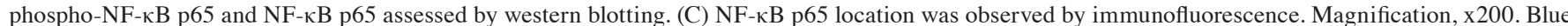

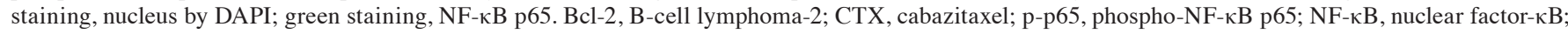
PC, prostate cancer; p-IKK $\alpha / \beta$, phospho-IKK $\alpha / \beta ;$ p-IкB $\alpha$, phospho-IкB $\alpha$.

pathway $(19,20)$. In the present study, cytoplasmic and nuclear proteins were extracted from PC cells following treatment with $10 \mathrm{nM}$ CTX for $0,1,3$ and $6 \mathrm{~h}$, and NF- $\mathrm{kB}$ p 65 expression was detected in both fractions by using western blotting. The results demonstrated that treatment with CTX induced an increase in NF- $\kappa \mathrm{B}$ p65 protein expression in the nucleus compared within the cytoplasm in the two PC cell lines (Fig. 2A). In addition, the results from IHC demonstrated that the translocation of NF- $\mathrm{KB}$ to the nucleus increased with CTX treatment (Fig. 2C). In addition, numerous proteins involved in the NF- $\kappa \mathrm{B}$ pathway were also examined by western blotting, including phospho-inbibitor of $\kappa B$ kinase (IKK) $\alpha / \beta$, phospho-inhibitor of $\kappa \mathrm{B}$ (IкB) $\alpha$ and phospho-NF- $\kappa \mathrm{B}$ p65. The results demonstrated that the expression of all these proteins was increased following treatment with CTX (Fig. 2B). These findings suggested that NF- $\mathrm{kB}$ pathway may influence CTX treatment efficiency.

$N F-\kappa B$ p 65 overexpression attenuates the effect of CTX. To evaluate the role of NF- $\mathrm{KB}$ p65 in CTX treatment, AsPC-1 and BxPC-3 cell lines overexpressing NF- $\kappa \mathrm{B}$ p 65 were constructed. Transfection efficiency was evaluated by western blotting. The results demonstrated that phospho-NF- $\kappa \mathrm{B}$ p65 was increased in NF-кB p65-overexpressing cells (Fig. 3A); however, no change in NF- $\kappa \mathrm{B}$ p65 expression was observed in the nucleus (Fig. 3B). Subsequently, control and transfected were treated with the same concentration gradient of CTX for $48 \mathrm{~h}$ in 96-well plates and cell proliferation was assessed by using CCK- 8 assay. The results demonstrated a decrease in sensitivity to CTX treatment in the NF- $\mathrm{kB}$ p65-overexpressing cells compared with control cells (Fig. 3C). These findings suggested that NF-kB p65 may affect CTX resistance.

Inhibiting $N F-\kappa B$ p 65 translocation to the nucleus enhances CTX efficiency by downregulating Bcl-2. To further evaluate the role of NF- $\mathrm{KB}$ p65 in CTX treatment efficiency, the NF- $\kappa \mathrm{B}$ inhibitor CAPE was used in combination with CTX in AsPC-1 and BxPC-3 cells. The toxicity of CAPE on PC cells was determined. The results demonstrated an absence of toxicity of CAPE, and the concentration of $5 \mu \mathrm{M}$ was chosen for further experiments (Figs. 3D and S2A). Subsequently, the effect of CTX combined with $5 \mu \mathrm{M}$ CAPE on PC cell proliferation was determined. The results demonstrated that CAPE enhanced cell sensitivity to CTX (Fig. 3E; Table I). Furthermore, cell apoptosis was increased following treatment with $5 \mathrm{nmol}$ CTX and $5 \mu \mathrm{mol} \mathrm{CAPE}$ for $48 \mathrm{~h}$, compared with treatment with 


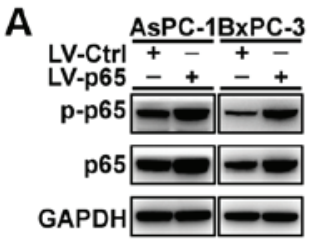

D

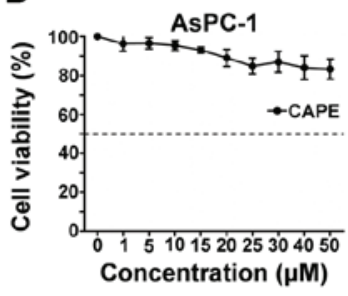

$\mathbf{F}$
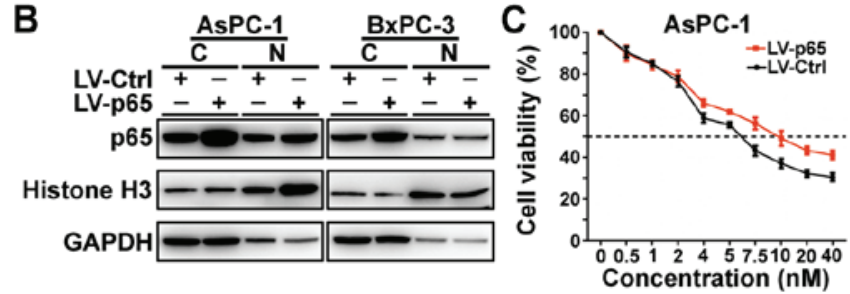

E
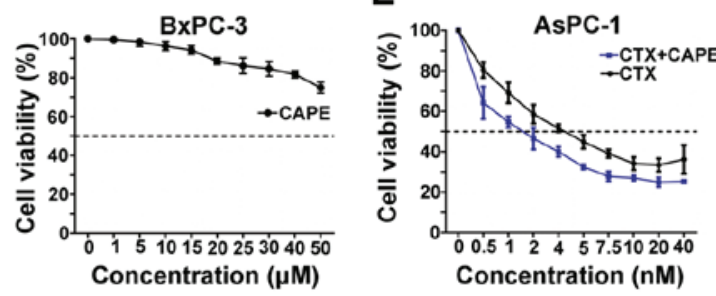

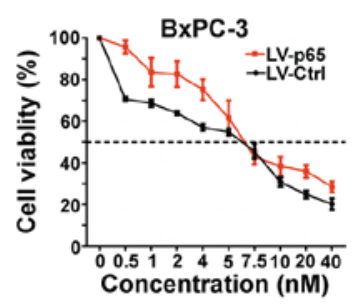

BxPC-3

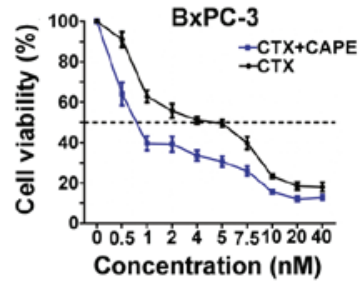

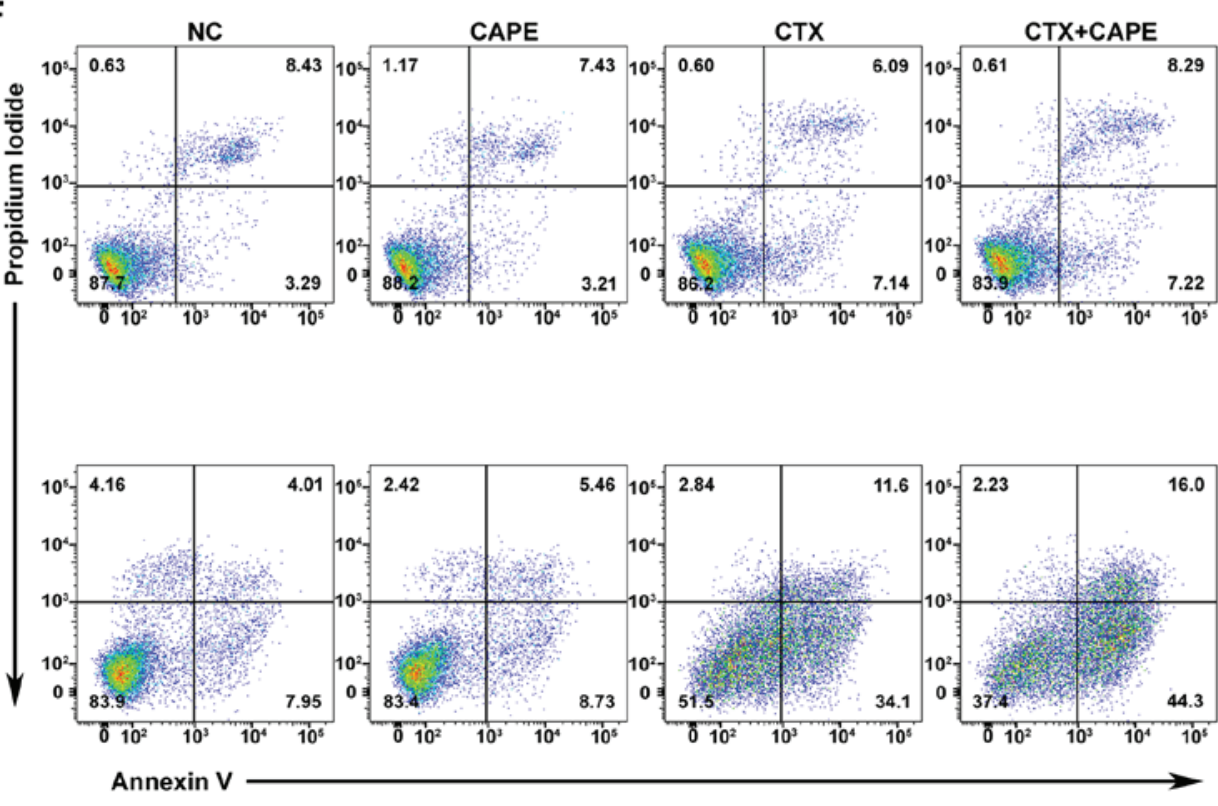
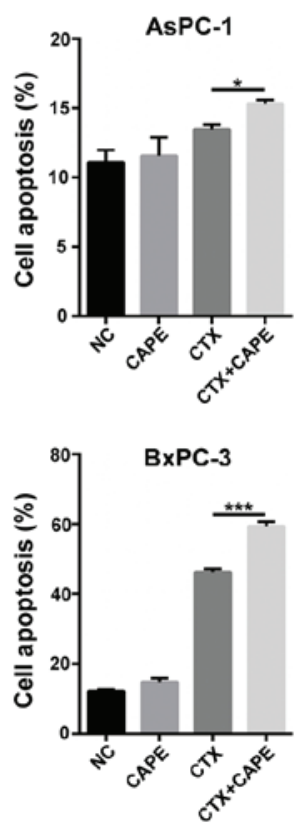

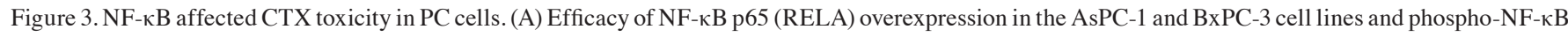
p65 expression were examined by western blotting. (B) NF- $\mathrm{kB}$ p65 protein expression in the nucleus was detected by western blotting following NF- $\mathrm{\kappa B}$ p65 overexpression. (C) CCK-8 assay was used to detect the sensitivity of the two cell lines to CTX in the control and NF-kB p65 overexpression groups. (D) CAPE cytotoxicity determined with the CCK-8 assay. (E) Effects of CTX combined to $5 \mu \mathrm{M} \mathrm{CAPE}$ on PC cell proliferation. (F) Apoptosis analysis of PC cells treated with CAPE $5 \mu \mathrm{M}$ CAPE, $5 \mathrm{nM}$ CTX or $5 \mathrm{nM}$ CTX and $5 \mu \mathrm{M}$ CAPE (left panel), and quantification of cell apoptosis in AsPC-1 and BxPC-3 cell lines (right panel). Data were presented as the means \pm standard error of the mean of three independent experiments. In AsPC-1 cell line, the apoptosis rate of CTX group was compared with CTX+CAPE group " $\mathrm{P}<0.05$. In BxPC-3 cell line, the apoptosis rate of CTX group was compared with CTX+CAPE group

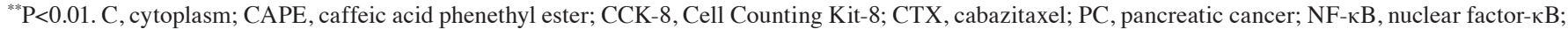
$\mathrm{N}$, nucleus; p-p65, phospho-NF-кB p65; NC, negative control.

$5 \mathrm{nmol}$ CTX alone (Fig. 3F). No significant difference in the cell cycle arrest was observed between treatment with CTX alone and combined treatment with CTX and CAPE (Fig. S2B). Furthermore, the results from drug combination assay (combination of CTX and CAPE at different concentration to treat AsPC-1 and BxPC-3) indicated that CAPE synergized with CTX (Fig. 4A and B). To evaluate the underlying mechanism driving apoptosis in PC cells following treatment with combination of CTX and CAPE, the protein expression of apoptosis-related proteins was detected. The results demonstrated a decline in Bcl-2 expression and an increase in cleaved-PARP expression (Fig. 4C). Subsequently, the role of NF- $\mathrm{KB}$ p65 in the regulation of $\mathrm{Bcl}-2$ protein expression was evaluated by using RT-qPCR. The results demonstrated that Bcl-2 mRNA level was significantly decreased following treatment with CTX and CAPE compared with CTX treatment alone (Fig. 4D). In addition, Bcl-2 protein expression was upregulated following NF- $\kappa$ B p65 overexpression (Fig. S2C). These findings suggested that CAPE may downregulate Bcl-2, mostly by inhibiting NF- $\mathrm{kB}$ p 65 translocation into the nucleus, leading to the enhancement of CTX pro-apoptotic effect.

Combination of CTX and CAPE is more effective in mouse xenograft models. Following mice treatment with drugs, the results demonstrated that combination of CTX and CAPE was more effective in inhibiting tumor growth according to the ratio of tumor weight to body weight compared with CTX treatment alone; however, there was no significant difference in the tumor volume between CTX and combination groups. In addition, CTX was significantly more effective at inhibiting 
A

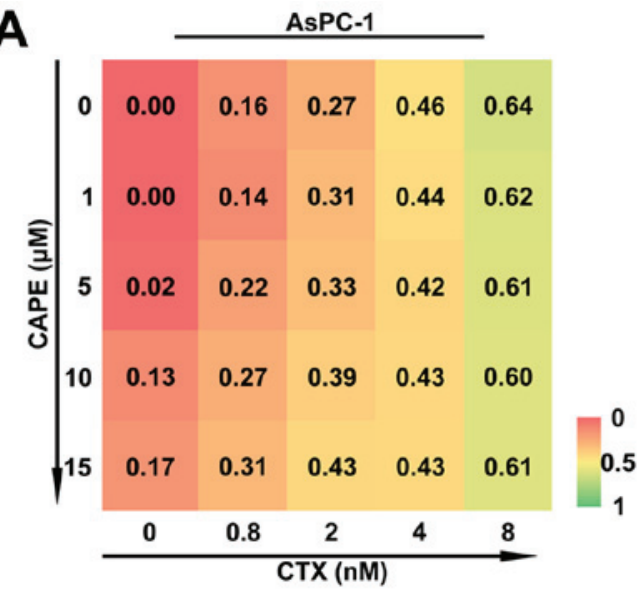

B

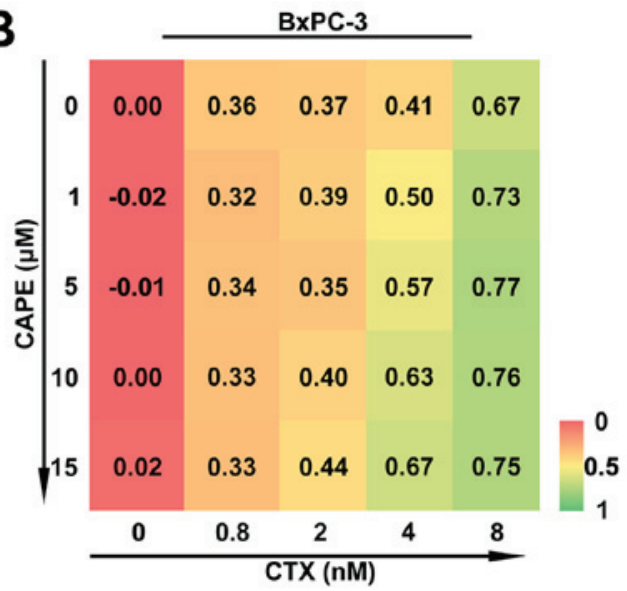

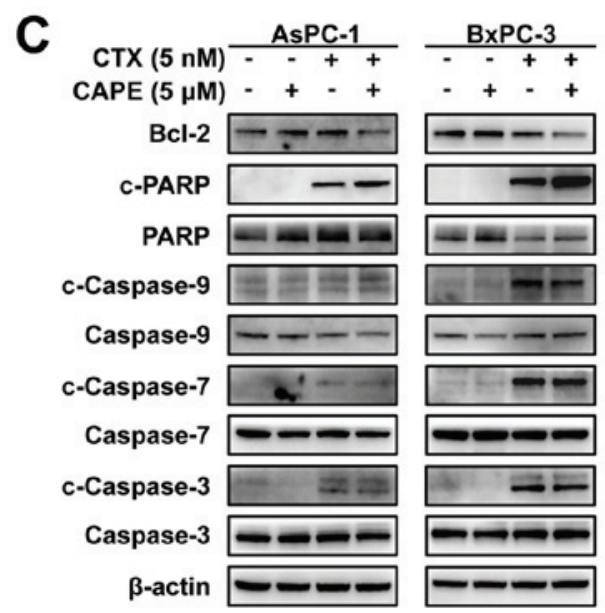

D
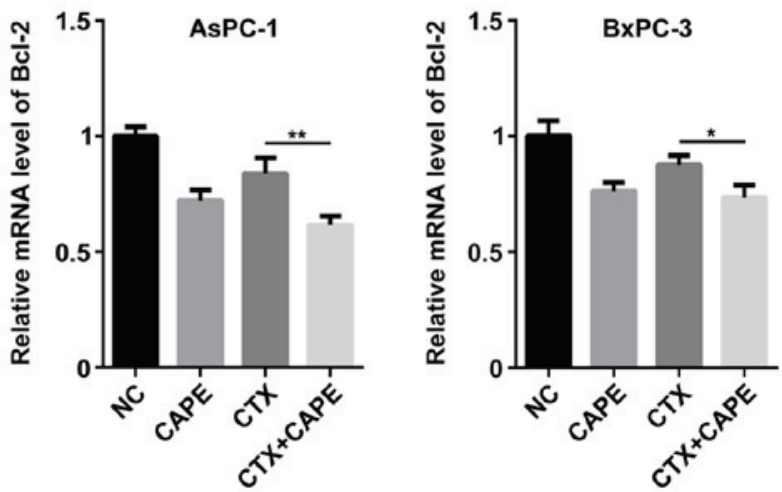

Figure 4. CAPE increased PC cell apoptosis by downregulating Bcl-2. (A and B) Drug combination assay revealed the synergy between CAPE and CTX. (C) Protein expression of apoptosis-related proteins between the negative control, $5 \mu \mathrm{M}$ CAPE, $5 \mathrm{nM} \mathrm{CTX}$, and $5 \mathrm{nM}$ CTX plus $5 \mu \mathrm{M}$ CAPE groups assessed by western blotting. (D) Relative mRNA level of Bcl-2 in determined by reverse transcription quantitative PCR. Data were presented as the mean \pm standard error of the mean of three independent experiments. In AsPC-1 cell line, the Bcl-2 mRNA level of CTX group was compared with CTX+CAPE group ** $\mathrm{P}<0.01$. In BxPC-3 cell line, the Bcl-2 mRNA level of CTX group was compared with CTX+CAPE group "P<0.05. Bcl-2, B-cell lymphoma-2; c, cleaved; CAPE, caffeic acid phenethyl ester; CTX, cabazitaxel; NC, negative control; PARP, poly (ADP-ribose) polymerase; PC, pancreatic cancer.

tumor growth in mouse xenograft models compared with PTX (Fig. 5A-C). These results were consistent with in vitro results from the present study (Figs. 1 and 3). Furthermore, BxPC-3 xenograft tumors were tested by IHC for PCNA. As presented in Fig. 5D, the presence of PCNA-positive cells was decreased in the combination group compared with the other groups, suggesting a decline in PC cell proliferation (Fig. 5D). Furthermore, the results from TUNEL assay demonstrated that the combination group was more efficient at inducing cell apoptosis (Fig. 5E).

\section{Discussion}

At present, the early diagnosis of PC remains difficult, and patients with $\mathrm{PC}$ present with a high recurrence rate following surgical resection. Administration of an effective adjuvant chemotherapy following resection is therefore crucial. Gemcitabine combined with albumin-bound PTX remians the main therapeutic option for patients with PC following surgical resection, or for patients with a good performance status and who are physically unable to undergo the procedure $(2,23)$. However, the high resistance rate of gemcitabine and PTX in $\mathrm{PC}$ remains a challenge. The main cause for drug resistance in $\mathrm{PC}$ is the upregulation of multidrug resistance-associated P-gp, which acts as a drug efflux pump (24-26). In addition, gemcitabine and PTX resistance is associated with P-gp high expression $(2,27)$. CTX is a semi-synthetic taxane that was developed to overcome PTX and DTX resistance (6,28-30). Compared with the other two types of taxanes, CTX has a poor affinity for P-gp, suggesting that patients treated with CTX might be less likely to develop resistance $(4,31)$. It is therefore crucial to develop a treatment alternative to PTX for patients with PC. In the present study, CTX sensitivity was compared with PTX in PC cell lines. The results from CCK-8 and colony formation assays demonstrated that CTX was more effective than PTX in inhibiting AsPC-1 and BxPC-3 cell proliferation. Furthermore, in PC cell lines, CTX was efficient at inducing cell cycle arrest in the $\mathrm{G} 2 / \mathrm{M}$ phase and promoting apoptosis at low concentration. In vivo, CTX also significantly inhibited tumor growth. However, treatment with same dose of PTX did not have the same effects. These findings suggested that CTX may be used in replacement of PTX in the treatment of PC.

$\mathrm{NF}-\kappa \mathrm{B}$ serves a crucial role in inflammation and immunity, and a previous study reported that $\mathrm{NF}-\kappa \mathrm{B}$ pathway activation is also important for tumor development (14). Reticuloendotheliosis (REL) protein family provided the main 

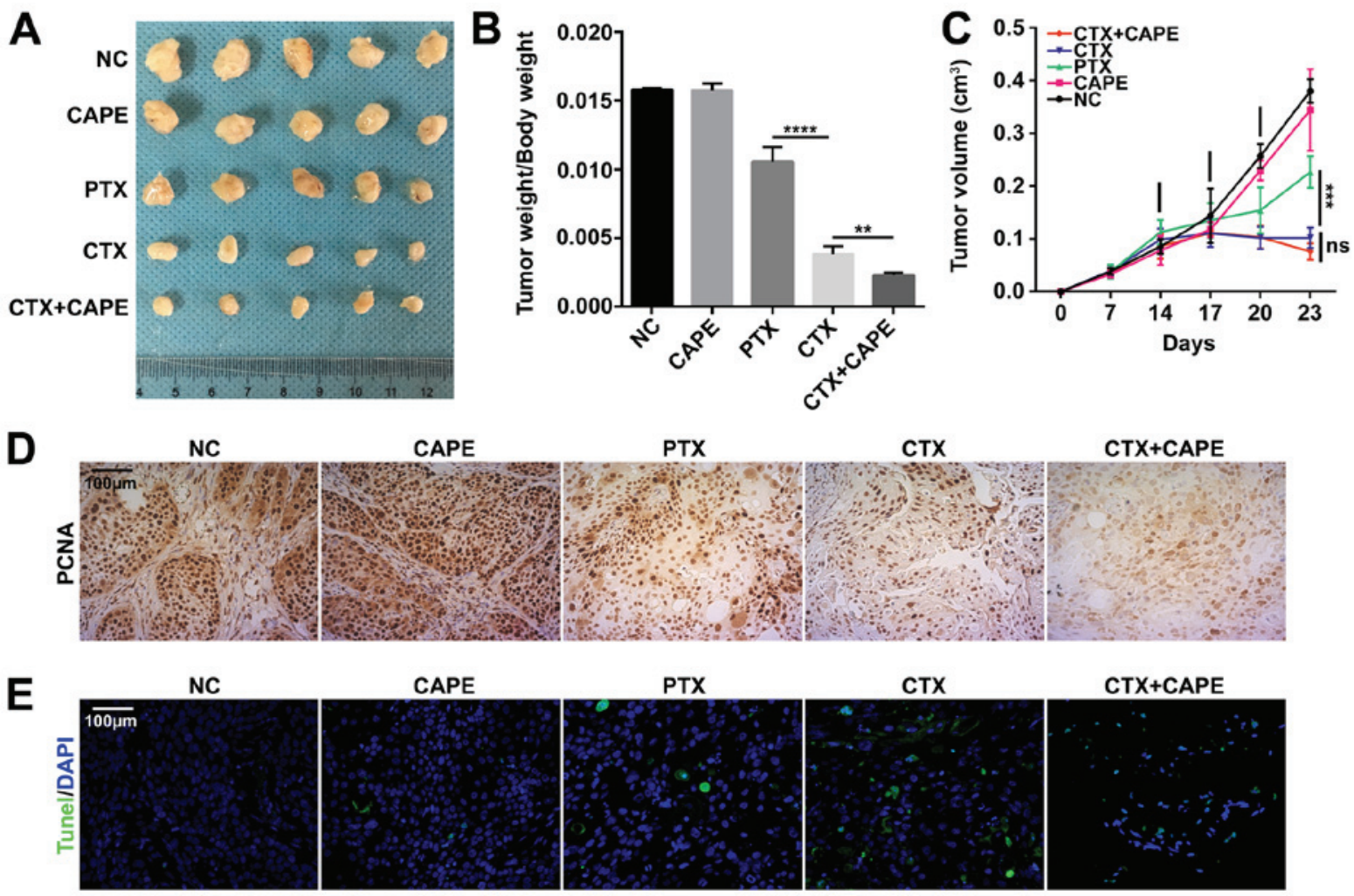

Figure 5. Effect of CAPE, CTX and PTX on PC tumor growth in vivo. (A) Tumor size collected in the five treatment groups (saline, CAPE at $10 \mathrm{mg} / \mathrm{kg}$, PTX at $10 \mathrm{mg} / \mathrm{kg}$, CTX at $10 \mathrm{mg} / \mathrm{kg}$ and CTX at $8 \mathrm{mg} / \mathrm{kg}$ plus CAPE $10 \mathrm{mg} / \mathrm{kg}$ ) at the end of the experiment. (B) Ratio of tumor weight to body weight and (C) tumor volume were compared between the five groups. Data were presented as the mean \pm standard error of the mean of five independent experiments. Tumor weight/body weight rate of CTX group was compared with CTX+CAPE group ${ }^{* *} \mathrm{P}<0.01$. Tumor weight/ body weight rate of PTX group was compared with CTX group. ${ }^{* * * *} \mathrm{P}<0.0001$. (D) Immunohistochemistry of tumor tissues stained for PCNA. Magnification, $\mathrm{x} 200$. (E) TUNEL staining of tumor tissues. The nucleus was stained blue by DAPI; green staining represents the TUNEL staining. Magnification, x200. CAPE, caffeic acid phenethyl ester; CTX, cabazitaxel; PCNA, proliferating cell nuclear antigen; PC, prostate cancer; PTX, paclitaxel.

evidence linking NF- $\mathrm{KB}$ to cancer. The main type of REL includes RELA, also known as $\mathrm{p} 65$. The first step of the classical $\mathrm{NF}-\kappa \mathrm{B}$ activation pathway is the activation of the IKK complex inhibitor. Subsequently, IKK phosphorylates the NF- $\mathrm{kB}$-bound $\mathrm{I} \kappa \mathrm{B}$, which contributes to the ubiquitin-dependent degradation of IкB, resulting in the nuclear translocation of the p65-p50 dimer (14). This process induces cancer cell proliferation and inhibit their apoptosis. Certain stimuli, including tumor necrosis factor- $\alpha, \mathrm{CD} 40 \mathrm{~L}$, interleukin-1 or lipopolysaccharides, can cause NF- $\mathrm{KB}$ pathway activation $(13,32)$. However, numerous studies reported that PTX can NF- $\mathrm{KB}$ pathway activation in immune or tumor cells $(19,20)$. Both CTX and PTX are taxanes, and CTX must be identical to PTX in some ways. In the present study, NF- $\mathrm{kB}$ activation was determined in PC cell lines treated by CTX by western blotting and immunofluorescence. The results demonstrated and increased nuclear translocation of NF- $\mathrm{KB}$ p65. In addition, phospho-IKK $\alpha / \beta$, phospho-I $\kappa \mathrm{B} \alpha$ and phospho-NF- $\kappa \mathrm{B}$ p65 were also upregulated in PC cells treated with CTX. Subsequently, it was important to determine whether NF- $\mathrm{kB}$ pathway activation may affect CTX cytotoxicity. To do so, AsPC-1 and BxPC-3 cell lines overexpressing NF- $\mathrm{kB}$ p 65 were designed, and cell proliferation following treatment with different concentrations of CTX was evaluated. The results demonstrated that NF-kB p65 overexpression attenuated CTX cytotoxicity, suggesting that NF-KB may serve a crucial role in PC cell sensitivity to CTX. Over the last decades, preclinical and clinical studies reported that NF- $\kappa \mathrm{B}$ activation serves a central role in drug resistance $(33,34)$. Subsequently, it is hypothesized that NF- $\kappa \mathrm{B}$ may influence CTX resistance. CTX exerts its effects mainly by binding to tubulin and therefore suppressing microtubule dynamics during cell division (31); however, the activation of NF- $\kappa B$ offset part of the effects that CTX made on the expression of cell apoptosis-related proteins and G2/M phase arrest-related proteins $(14,35)$. As a nuclear factor, NF- $\mathrm{KB}$ might regulate the transcription of apoptosis-related proteins and G2/M phase arrest-related proteins, leading to CTX resistance. The results from the present study demonstrated that Bcl-2 may be regulated by NF- $\mathrm{kB}$; however, further investigation is required to confirm this hypothesis. At present, there are only a few reports on CTX resistance, and no cell or animal models of CTX resistance have been studied.

In the present study, an inhibitor of NF- $\mathrm{kB}$ was selected to explore the pharmacological effects of CTX. CAPE is a specific inhibitor of NF- $\mathrm{KB}$ activation that doesn't function by blocking the degradation of $\mathrm{I} \mathrm{K} \mathrm{B} \alpha$, but by directly suppressing NF- $\kappa B$ protein interaction with DNA $(21,36,37)$. The present study demonstrated that combination of CTX with CAPE had better effects on the inhibition of $\mathrm{PC}$ cell proliferation and the stimulation of PC cell apoptosis compared with CTX alone. Furthermore, results from in vivo experiments demonstrated that tumor growth inhibition was significantly increased in the combination group compared with the group treated with CTX alone. Previous clinical studies reported that CTX can greatly 
improve the survival of patients with prostate cancer $(6,11)$; however, some adverse effects are observed when patients received intravenous injection of $25 \mathrm{mg} / \mathrm{m}^{2} \mathrm{CTX}$ over $1 \mathrm{~h}$ every 3 week (38), which is also the case with other taxanes. The present study demonstrated therefore that the combination of CTX and CAPE may allow the diminution of CTX dose, which may alleviate the potential onset of side effects. Previous studies reported that $\mathrm{Bcl}-2$ expression is regulated by $\mathrm{NF}-\kappa \mathrm{B}$ signaling $(39,40)$. The present study demonstrated that Bcl-2 was downregulated following treatment with the $\mathrm{NF}-\kappa \mathrm{B}$ inhibitor CAPE, and the increased cleaved-PARP expression could explain the increased apoptosis in the combination group. The findings from the present study highlighted the potential synergy between CTX and CAPE, and suggested that CAPE may enhance CTX pharmacological effects in patients with PC.

CTX is a drug without any modification used in our study, however, albumin-bound PTX is a clinical drug that uses albumin as a carrier for PTX. In order to eliminate the effect of albumin on the experiment, PTX was chosen in the present study. Previous studies have reported nanoparticle-CTX delivery (41-43). The present study provided evidence for the use of modified CTX to replace albumin-bound PTX in PC treatment, due to its low resistance rate and its strong effect on tumor growth inhibition. The present study also highlighted the crucial role of $\mathrm{NF}-\kappa \mathrm{B}$ activation in PC cell sensitivity to CTX. $\mathrm{NF}-\kappa \mathrm{B}$ inhibition enhanced CTX-induced toxicity in PC cells, suggesting that activation of NF- $\kappa \mathrm{B}$ may influence CTX resistance. However, further investigation is required to validate this hypothesis. In addition, combining CTX with a NF- $\mathrm{B}$ inhibitor may be considered as an effective way to reduce CTX dosage, which may therefore decrease CTX-mediated adverse effects. Clinical trial including patients with PC is therefore required to improve the response prediction of CTX and optimize therapeutic options for patients. The results from the present study indicated that CTX may be used in the clinical treatment of patients with PC.

\section{Acknowledgements}

Not applicable.

\section{Funding}

This study was supported by the Innovative Research Groups of National Natural Science Foundation of China (grant no. 81721091), the Major program of National Natural Science Foundation of China (grant no. 91542205), the National Natural Science Foundation of China (grant nos. 81570575 and 81870434) and the National S\&T Major Project (grant no. 2017ZX10203205).

\section{Availability of data and materials}

All data analyzed during this study are included in this published article.

\section{Authors' contributions}

$\mathrm{ZL}$ and $\mathrm{ZX}$ designed the study. ZL wrote the manuscript. ZL, JC and SZ performed cell experiments, western blotting,
RT-qPCR, apoptosis and cell cycle analyses. WS, CJ and MZ performed animal experiments. ZL and WS contributed to statistical analysis and designed the table and figures. PS and SZ were involved in project management and supervised the study. All authors read and approved the final manuscript.

\section{Ethics approval and consent to participate}

This study was approved by the Tab of Animal Experimental Ethical Inspection of the First Affiliated Hospital, College of Medicine, Zhejiang University.

\section{Patient consent for publication}

Not applicable.

\section{Competing interests}

The authors declare that they have no competing interests.

\section{References}

1. Ryan DP, Hong TS and Bardeesy N: Pancreatic adenocarcinoma. N Engl J Med 371: 1039-1049, 2014.

2. Kamisawa T, Wood LD, Itoi T and Takaori K: Pancreatic cancer. Lancet 388: 73-85, 2016.

3. Hartwig W, Werner J, Jäger D, Debus J and Büchler MW: Improvement of surgical results for pancreatic cancer. Lancet Oncol 14: e476-e485, 2013.

4. Galsky MD, Dritselis A, Kirkpatrick P and Oh WK: Cabazitaxel. Nat Rev Drug Discov 9: 677-678, 2010.

5. Seruga B and Tannock IF: Chemotherapy-based treatment for castration-resistant prostate cancer. J Clin Oncol 29: 3686-3694, 2011.

6. Dorff TB and Quinn DI: Cabazitaxel in prostate cancer: Stretching a string. Lancet 376: 1119-1120, 2010.

7. Kotsakis A, Matikas A, Koinis F, Kentepozidis N, Varthalitis II, Karavassilis V, Samantas E, Katsaounis P, Dermitzaki EK, Hatzidaki D, et al: A multicentre phase II trial of cabazitaxel in patients with advanced non-small-cell lung cancer progressing after docetaxel-based chemotherapy. Br J Cancer 115: 784-788, 2016.

8. Chen R, Cheng Q, Owusu-Ansah KG, Chen J, Song G, Xie H, Zhou L, Xu X, Jiang D and Zheng S: Cabazitaxel, a novel chemotherapeutic alternative for drug-resistant hepatocellular carcinoma. Am J Cancer Res 8: 1297-1306, 2018.

9. Zhong T, He B, Cao HQ, Tan T, Hu HY, Li YP and Zhang ZW: Treating breast cancer metastasis with cabazitaxel-loaded polymeric micelles. Acta Pharmacol Sin 38: 924-930, 2017.

10. 10. Kunos CA, Stefan T and Jacobberger JW: Cabazitaxel-induced stabilization of microtubules enhances radiosensitivity in ovarian cancer cells. Front Oncol 3: 226, 2013.

11. Abidi A: Cabazitaxel: A novel taxane for metastatic castration-resistant prostate cancer-current implications and future prospects. J Pharmacol Pharmacother 4: 230-237, 2013.

12. Yang Y, Bteich J and Li SD: Current update of a carboxymethylcellulose-PEG conjugate platform for delivery of insoluble cytotoxic agents to tumors. AAPS J 19: 386-396, 2017.

13. Baldwin AS Jr: The NF-kappa B and I kappa B proteins: New discoveries and insights. Annu Rev Immunol 14: 649-683, 1996.

14. Karin M, Cao Y, Greten FR and Li ZW: NF-kappaB in cancer: From innocent bystander to major culprit. Nat Rev Cancer 2: 301-310, 2002.

15. Awasthee N, Rai V, Chava S, Nallasamy P, Kunnumakkara AB Bishayee A, Chauhan SC, Challagundla KB and Gupta SC: Targeting IкарраB kinases for cancer therapy. Semin Cancer Biol 56: 12-24, 2019.

16. Rajagopal C, Lankadasari MB, Aranjani JM and Harikumar KB: Targeting oncogenic transcription factors by polyphenols: A novel approach for cancer therapy. Pharmacol Res 130: 273-291, 2018.

17. Zaidi AH, Raviprakash N, Mokhamatam RB, Gupta P and Manna SK: Profilin potentiates chemotherapeutic agents mediated cell death via suppression of $\mathrm{NF}-\mathrm{\kappa B}$ and upregulation of p53. Apoptosis 21: 502-513, 2016. 
18. Li Q, Yang G, Feng M, Zheng S, Cao Z, Qiu J, You L, Zheng L, $\mathrm{Hu} Y$, Zhang T, et al: NF- $\mathrm{BB}$ in pancreatic cancer: Its key role in chemoresistance. Cancer Lett 421: 127-134, 2018.

19. Das KC and White CW: Activation of NF-kappaB by antineoplastic agents. Role of protein kinase C. J Biol Chem 272: 14914-14920, 1997.

20. Perera PY, Qureshi N and Vogel SN: Paclitaxel (Taxol)-induced NF-kappaB translocation in murine macrophages. Infect Immun 64: 878-884, 1996.

21. Natarajan K, Singh S, Burke TR Jr, Grunberger D and Aggarwal BB: Caffeic acid phenethyl ester is a potent and specific inhibitor of activation of nuclear transcription factor NF-kappa B. Proc Natl Acad Sci USA 93: 9090-9095, 1996.

22. Livak KJ and Schmittgen TD: Analysis of relative gene expression data using real-time quantitative PCR and the 2(-Delta Delta C(T)) method. Methods 25: 402-408, 2001.

23. Mohammed S, Van Buren G II and Fisher WE: Pancreatic cancer: Advances in treatment. World J Gastroenterol 20: 9354-9360, 2014

24. Lin QJ, Yang F, Jin C and Fu DL: Current status and progress of pancreatic cancer in China. World J Gastroenterol 21: 7988-8003, 2015.

25. Hagmann W, Faissner R, Schnölzer M, Löhr M and Jesnowski R: Membrane drug transporters and chemoresistance in human pancreatic carcinoma. Cancers (Basel) 3: 106-125, 2010.

26. LuZ,Kleeff J,Shrikhande S,Zimmermann T, Korc M, Friess H and Büchler MW: Expression of the multidrug-resistance 1 (MDR1) gene and prognosis in human pancreatic cancer. Pancreas 21: 240-247, 2000

27. Ezrahi S, Aserin A and Garti N: Basic principles of drug delivery systems - the case of paclitaxel. Adv Colloid Interface Sci 263: 95-130, 2019

28. Di Lorenzo G, Buonerba C, Autorino R, De Placido S and Sternberg CN: Castration-resistant prostate cancer: Current and emerging treatment strategies. Drugs 70: 983-1000, 2010.

29. Zeng YY, Zeng YJ, Zhang NN, Li CX, Xie T and Zeng ZW: The preparation, determination of a flexible complex liposome co-loaded with cabazitaxel and $\beta$-elemene, and animal pharmacodynamics on paclitaxel-resistant lung adenocarcinoma. Molecules 24: 24, 2019

30. Vrignaud P, Sémiond D, Lejeune P, Bouchard H, Calvet L, Combeau C, Riou JF, Commerçon A, Lavelle F and Bissery MC: Preclinical antitumor activity of cabazitaxel, a semisynthetic taxane active in taxane-resistant tumors. Clin Cancer Res 19: 2973-2983, 2013.

31. Villanueva C, Bazan F, Kim S, Demarchi M, Chaigneau L, Thiery-Vuillemin A, Nguyen T, Cals L, Dobi E and Pivot X: Cabazitaxel: A novel microtubule inhibitor. Drugs 71: 1251-1258, 2011.

32. Wang CY, Mayo MW and Baldwin AS Jr: TNF- and cancer therapy-induced apoptosis: Potentiation by inhibition of NF-kappaB. Science 274: 784-787, 1996.

33. Ju HQ, Li H, Tian T, Lu YX, Bai L, Chen LZ, Sheng H, Mo HY, Zeng JB, Deng W, et al: Melatonin overcomes gemcitabine resistance in pancreatic ductal adenocarcinoma by abrogating nuclear factor- $\mathrm{\kappa B}$ activation. J Pineal Res 60: 27-38, 2016.
34. Qiao Q, Sun C, Han C, Han N, Zhang M and Li G: Endoplasmic reticulum stress pathway PERK-eIF2 $\alpha$ confers radioresistance in oropharyngeal carcinoma by activating NF- $\kappa$ B. Cancer Sci 108: 1421-1431, 2017.

35. Peng J, Hamanishi J, Matsumura N, Abiko K, Murat K, Baba T, Yamaguchi K, Horikawa N, Hosoe Y, Murphy SK, et al: Chemotherapy induces programmed cell death-ligand 1 overexpression via the nuclear factor- $\kappa \mathrm{B}$ to foster an immunosuppressive tumor microenvironment in ovarian cancer. Cancer Res 75: 5034-5045, 2015.

36. Wu J, Omene C, Karkoszka J, Bosland M, Eckard J, Klein CB and Frenkel K: Caffeic acid phenethyl ester (CAPE), derived from a honeybee product propolis, exhibits a diversity of anti-tumor effects in pre-clinical models of human breast cancer. Cancer Lett 308: 43-53, 2011.

37. Park MH, Kang DW, Jung Y, Choi KY and Min S: Caffeic acid phenethyl ester downregulates phospholipase D1 via direct binding and inhibition of $\mathrm{NF} \kappa \mathrm{B}$ transactivation. Biochem Biophys Res Commun 442: 1-7, 2013.

38. de Bono JS, Oudard S, Ozguroglu M, Hansen S, Machiels JP, Kocak I, Gravis G, Bodrogi I, Mackenzie MJ, Shen L, et al; TROPIC Investigators: Prednisone plus cabazitaxel or mitoxantrone for metastatic castration-resistant prostate cancer progressing after docetaxel treatment: A randomised open-label trial. Lancet 376: 1147-1154, 2010.

39. Kong R, Sun B, Jiang H, Pan S, Chen H, Wang S, Krissansen GW and Sun X: Downregulation of nuclear factor-kappaB p 65 subunit by small interfering RNA synergizes with gemcitabine to inhibit the growth of pancreatic cancer. Cancer Lett 291: 90-98, 2010.

40. Yuan Z, Jiang H, Zhu X, Liu X and Li J: Ginsenoside Rg3 promotes cytotoxicity of Paclitaxel through inhibiting NF- $\mathrm{KB}$ signaling and regulating $\mathrm{Bax} / \mathrm{Bcl}-2$ expression on triple-negative breast cancer. Biomed Pharmacother 89: 227-232, 2017.

41. Xie B, Wan J, Chen X, Han W and Wang H: Preclinical evaluation of a cabazitaxel prodrug using nanoparticle delivery for the treatment of taxane-resistant malignancies. Mol Cancer Ther 19: 822-834, 2019.

42. Meng F, Sun Y, Lee RJ, Wang G, Zheng X, Zhang H, Fu Y, Yan G, Wang Y, Deng W, et al: Folate receptor-targeted albumin nanoparticles based on microfluidic technology to deliver cabazitaxel. Cancers (Basel) 11: 11, 2019.

43. Ren T, Wang Q, Xu Y, Cong L, Gou J, Tao X, Zhang Y, He H, Yin T, Zhang $\mathrm{H}$, et al: Enhanced oral absorption and anticancer efficacy of cabazitaxel by overcoming intestinal mucus and epithelium barriers using surface polyethylene oxide (PEO) decorated positively charged polymer-lipid hybrid nanoparticles. J Control Release 269: 423-438, 2018.

This work is licensed under a Creative Commons Attribution-NonCommercial-NoDerivatives 4.0 International (CC BY-NC-ND 4.0) License. 